nancy was associated with disappearance of activity and relapse after delivery with its reappearance.

Carbimazole in high dosage ( $45 \mathrm{mg} /$ day) has an immunosuppressive effect on thyroid autoantibody values in Graves' disease. ${ }^{5}$ Though lower doses were used in our study, treatment with carbimazole may have been responsible for the loss of activity of the protector in five out of seven drug treated pregnancies, with its return in three patients after delivery being a rebound effect after withdrawal of the drug. Of 24 patients with toxic Graves' disease treated for one year using similar doses of carbimazole, however, long acting thyroid stimulator protector disappeared in only six. ${ }^{2}$

An alternative explanation is that pregnancy itself has a direct effect on the underlying process causing Graves' disease. Similar changes to those seen in this study have been observed in other thyroid autoantibody values during and after pregnancy associated with autoimmune thyroid disease. ${ }^{6}$ Some of the patients were hypothyroid and were therefore not taking carbimazole. No firm conclusion can be drawn from our findings in one euthyroid patient previously treated by subtotal thyroidectomy. Further studies are indicated in this group of patients with a history of Graves' disease who do not require drug treatment.
This work was supported by a grant from the Yorkshire Cancer Research Campaign.

\section{References}

${ }^{1}$ Dirmikis S. Some factors affecting the detection of long acting thyroid stimulator protector using the McKenzie bioassay. $\mathcal{F}$ Endocrinol $1974 ; 63$ : 427-38.

${ }^{2}$ Hardisty CA, Munro DS. Relationship between long acting thyroid stimulator protector and the course of Graves's disease. In: Stockiet JR, Nagataki S, eds. Thyroid research VIII. Melbourne: Australian Academy of Science, 1980:613-6.

${ }^{3}$ Man EB, Shaver BA, Cooke RE. Studies of children born to mothers with thyroid disease. Am $\mathcal{F}$ Obstet Gynecol 1958;75:728-41.

4 Munro DS, Dirmikis SM, Humphries H, Smith T, Broadhead GD. The role of thyroid stimulating immunoglobulins of Graves's disease in neonatal thyrotoxicosis. Br F Obstet Gynaecol 1978;85:837-43.

5 McGregor AM, Petersen MM, McLachlan SM, Rooke P, Smith BR, Hall R. Carbimazole and the autoimmune response in Graves' disease. $N$ Engl f Med 1980;303:302-7.

${ }^{6}$ Amino $\mathrm{N}$, Kuro $\mathrm{R}$, Tanizawa $\mathrm{O}$, et al. Change of serum antithyroid antibodies during and after pregnancy in autoimmune thyroid diseases. Clin Exp Immunol 1978;31:30-7.

(Accepted 21 fanuary 1983)

\title{
Glucose polymer supplementation of feeds for very low birthweight infants
}

\author{
A RAFFLES, G SCHILLER, P ERHARDT, M SILVERMAN
}

\begin{abstract}
The feeds of 14 very low birthweight infants (birth weight $<1500 \mathrm{~g}$ ) were supplemented with a glucose polymer (Caloreen) at the rate of $6 \mathrm{~g} / \mathrm{kg}$ body weight daily. Seven day periods of supplementation were alternated with seven day periods of normal feeding. Adding the glucose polymer significantly increased the rate of weight gain in these infants from $105 \mathrm{~g} /$ week to $140 \mathrm{~g} /$ week; growth rates in terms of length and head circumference were not affected. No adverse effects were noted.
\end{abstract}

Glucose polymer is a useful energy supplement for very low birthweight infants.

\section{Introduction}

The optimum method of nourishing infants of very low birth weight (less than $1500 \mathrm{~g}$ ) is controversial. ${ }^{1-3}$ Poor rates of growth are common despite maximum acceptable volumes of feed. There is concern that high fluid loads may contribute to morbidity in several ways, so that altering the composition of infant milk seems the simplest solution. Adding fat to the milk is of little advantage as it increases metabolic rate at the expense of

\section{Royal Postgraduate Medical School, Hammersmith Hospital,} London W12 OHS

A RAFFLES, DCH, MRCP, senior house officer in neonatal paediatrics G SCHILLER, MB, BS, senior house officer in neonatal paediatrics P ERHARDT, MRCP, senior house officer in neonatal paediatrics M SILVERMAN, MD, FRCP, consultant senior lecturer in paediatrics

Correspondence to: Dr $M$ Silverman. growth, ${ }^{4}$ while increasing the sugar content may lead to an excessively high osmolality with the risk of diarrhoea.

We have investigated the use of a glucose polymer (Caloreen) as a food supplement for infants of very low birth weight. This polymer exerts one fifth of the osmotic pressure of an isoenergetic solution of glucose. It is rapidly cleared from the stomach and absorbed in neonates ${ }^{6-9}$ and is converted to glucose intracellularly, giving a slow rise and sustained plateau of the plasma glucose concentration. There is no published information on the nutritional effects of this widely used substance in preterm infants.

\section{Patients and methods}

During the study babies weighing under $1500 \mathrm{~g}$, whether appropriate for gestational age or small for gestational age, were considered eligible for the trial provided that they were well and receiving all their nutrition by gastric tube. In particular, no infant was receiving phototherapy, oxygen, or intravenous fluids, was known to be suffering from infection, or had any condition requiring a restricted fluid regimen-for example, patent ductus arteriosus.

A crossover design was adopted. ${ }^{10}$ Glucose polymer supplementation periods of one week were alternated with control periods, the order of the first period being allocated at random. Fourteen infants completed at least two weeks of the study (table I). The total number of crossover periods was 40: four infants completed four crossover periods, four completed three periods, and six completed two periods.

TABLE I-Details of patients (values are means $\pm 1 S D ; n=14$ )

\begin{tabular}{cccc}
\hline $\begin{array}{c}\text { Gestational age } \\
\text { at birth (weeks) }\end{array}$ & $\begin{array}{c}\text { Postnatal age on } \\
\text { entry to study } \\
\text { (days) }\end{array}$ & Birth weight & $\begin{array}{c}\text { Weight on entry } \\
\text { to study (g) }\end{array}$ \\
\hline $28 \cdot 8 \pm 2 \cdot 1$ & $18 \cdot 1 \pm 10 \cdot 3$ & $969 \pm 123$ & $890 \pm 56$ \\
\hline
\end{tabular}


Several other infants did not complete the study because of early transfer to other hospitals or home, inadvertent change in the type of feed, or the development of signs of systemic infection. No complications of glucose polymer supplementation were detected.

All the infants were given intermittent (every two or three hours) nasogastric tube feeds of either Cow and Gate Premium (cows' milk formula) or pooled heat treated expressed breast milk at a rate of 150 $180 \mathrm{ml} / \mathrm{kg}$ daily. Glucose polymer $6 \mathrm{~g} / \mathrm{kg}$ daily was mixed with each day's feed during supplementation periods. Once a volume was established the infant kept to this throughout, the amount increasing only in proportion to any increase in weight.

Body weight was measured on an infant balance (Weighmaster, Marsden's Weighing Machines) at midnight on each day of the trial. Accuracy of the balance was checked on each occasion using a standard $1000 \mathrm{~g}$ weight. Occipitofrontal circumference was measured to the nearest millimetre at the beginning and end of each week using a fibreglass tape. Crown-heel length was measured at the beginning and end of each week with the Cardiff Neonatal Stadiometer (Holtain) All measurements of occipitofrontal circumference and length were made by AR or GS.

Paired $t$ tests were used to compare growth during supplementation and control periods.

\section{Results}

Weight gain varied between 60 and $240 \mathrm{~g}$ a week and was significantly greater during the glucose polymer supplementation weeks (table II). The mean increases in occipitofrontal circumference and length were similar during the supplementation and control periods.

TABLE II-Results of dietary supplementation with glucose polymer (values are means $\pm S D$ )

\begin{tabular}{lccc}
\hline & $\begin{array}{c}\text { Weight gain } \\
\text { (g/week) }\end{array}$ & $\begin{array}{c}\text { Increase in } \\
\text { length (mm/week) }\end{array}$ & $\begin{array}{c}\text { Increase in } \\
\text { occipitofrontal } \\
\text { circumference } \\
\text { (mm/week) }\end{array}$ \\
\hline $\begin{array}{l}\text { Control period } \\
\text { Glucose polymer } \\
\text { supplementation }\end{array}$ & $105 \pm 41$ & $13 \cdot 0 \pm 8$ & $9 \cdot 9 \pm 3$ \\
\hline $\begin{array}{l}\text { No of pairs of } \\
\text { observations }\end{array}$ & $140 \pm 41$ & $11 \cdot 7 \pm 8$ & $8 \cdot 8 \pm 4$ \\
$\begin{array}{l}\text { Value (control } v \\
\text { supplementation } \\
\text { period) }\end{array}$ & 27 & 21 & 21 \\
\hline
\end{tabular}

NS $=$ Not statistically significant

\section{Discussion}

These findings show that adding a glucose polymer $(6 \mathrm{~g} / \mathrm{kg} /$ day) to the feeds of infants of very low birth weight-that is, an $18 \%$ energy supplementation-can, within one week, significantly increase the rate of weight gain. During the study the rates of gain in occipitofrontal circumference and length were not altered. Adding glucose polymer with an energy value of $4 \mathrm{kcal} / \mathrm{g}$ $(16 \cdot 7 \mathrm{~kJ} / \mathrm{g})$ to feeds provided a low osmolar feed of high energy density. It was readily miscible in warm milk and was well tolerated by our patients, in particular causing no diarrhoea.

Various people have questioned the adequacy of human milk for the growth of premature infants. ${ }^{1-3}$ The rapid increase in weight, length, and head circumference in the third trimester has not been successfully achieved away from the placenta, and the relative undernutrition that the premature baby receives may impair brain growth and development. Supplementary feeds with medium chain triglycerides do not appear to benefit the neonate. It has been shown that short term high energy feeding leads to an increase in metabolic rate at the expense of growth, which is disadvantageous to the infant.

Studies of energy balance show wide infant to infant variation, the only clear relation being between energy retention and weight gain. ${ }^{11} 12$

It is interesting to speculate on the nature of the extra gain in weight with supplementation. None of our infants became clinically overloaded with fluid or developed peripheral oedema, nor did weight loss occur on withdrawing supplementation at the $m$ start of a control period, as might be expected if a labile pool of stored material had accumulated. The extra mass may have $\mathbb{D}$ been stored as fat or as glycogen but no part of the study was $\stackrel{2}{c}$ designed to investigate this. All the babies in this trial were well. It is difficult to judge whether similar results would be obtained from sick babies.

The design of the trial did not allow us to study long periods of growth. It is not surprising that, with weekly measurements, m changes in rates of growth, of length, and occipitofrontal circum- $\frac{?}{.}$ ference in the groups studied were no different. A parallel study $\overrightarrow{\vec{F}}$ for a four or eight week period would be required.

We would not advise the routine energy supplementation of $\bar{C}$ expressed breast milk or of "humanised" cows' milk feeds to infants of very low birth weight until it has been shown that $\frac{5}{D}$ true growth (in length and head size) can be thus achieved. ¿ Short term energy supplementation using glucose polymer may, ڤ however, be useful for infants who are failing to grow, who have $\vec{\circ}$

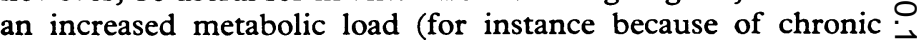
lung disease), or in whom only a restricted fluid intake is possible.

We thank Miss M B Castle and the nursing staff of the premature baby unit for their help and interest in this study. We are also grateful to Dr Pamela Davies for helpful comments.

\section{References}

1 Anonymous. Feeding infants of low birth weight. Br Med $\mathcal{F} 1979$;ii: 1092-3.

${ }^{2}$ Davies DP, Evans TJ. Nutrition and early growth of preterm infants. 은 Early Hum Dev 1978;2:383-92.

${ }^{3}$ Finberg L. One milk for all-not ever likely and certainly not yet. $\exists \vec{\omega}$ Pediatr 1980;96:240-1.

4 Brooke OG. Energy balance and metabolic rate in preterm infants fed with standard and high energy formulae. Br $\mathcal{F}$ Nutr 1980;44:13-23.

5 Hanmer OJ, Houlsby WT, Thom H, Ross IS, Lloyd DJ, Russell G. I Fat as an energy supplement for preterm infants. Arch Dis Child $\overrightarrow{0}$ 1982;57:503-6.

6 Husband J, Husband P, Mallinson CN. Gastric emptying of starch meals in the newborn. Lancet $1970 ;$ ii :290-2.

7 Costalos C, Russell G, Al Rahim Q, Blumenthal I, Hanlin S, Ross I. \ Gastric empyting of Caloreen meals in the newborn. Arch Dis Child $1980 ; 55: 883-5$.

${ }^{8}$ Russell G, Costalos C. Oral tolerance of Caloreen in babies. Arch Dis Child 1980;55:886-7.

9 Hunt LI, Antonsen DL, Paxson CL Jr, Vanderhoof JA. Osmolality of carbohydrate solutions and gastric empyting in the newborn. Am $\mathcal{f}$ 윽 Dis Child 1982;136:448-51.

10 Hills M, Armitage P. The two period cross over clinical trial. $\mathrm{Br} f \mathrm{Clin}$ Pharmacol 1979;8:7-20.

1 Brooke OG, Alvear J, Arnold M. Energy retention, energy expenditure and growth in healthy immature infants. Pediatr Res 1979;13:215-20.

12 Chessex P, Reichman BL, Verellen GJE, et al. Influence of postnatal age, energy intake and weight gain on energy metabolism in the very low birth weight infant. $\mathcal{F}$ Pediatr 1981 ;99:761-6.

(Accepted 20 fanuary 1983)

\section{Correction}

Comparison of four methods of smoking withdrawal in patients with smoking related diseases

The subcommittee of the Research Committee of the British Thoracic $\omega$ Society regrets that errors occurred in this paper (19 February, pp 595-7). The section in the results headed "Patients' opinions of the gums and side effects volunteered" should have read: "Of 568 patients who replied to the question at three months, just over half said they had found placebo and $\&$ Nicorette chewing gums helpful and $61 \%$ (330 of 544 replies) found them :unpleasant, with no significant difference between active and placebo $\frac{T}{T}$ gums in these respects. Of 494 patients who replied, $68 \%$ said that they were still using placebo or active gum at three months. Bad taste $(15 \%)$, nausea $(6 \%)$, and sore throat $(2 \%)$ were experienced more often with $\frac{\overrightarrow{\mathbb{D}}}{}$ nicotine than with placebo gum, but burning taste $(6 \%)$, flatulence $(5 \%)$, 으 and dental problems $(3 \%)$ were no more common with nicotine gum than with placebo."

The discussion also needs to be amended. At six months only patients 8 claiming to be non-smokers were asked whether they were still using chewing gum; consequently, the last sentence of the second paragraph of the Discussion is inappropriate and should have been deleted. 